\author{
Marek Kot \\ Wroclaw University of Economics and Business \\ e-mail: marek.kot@ue.wroc.pl \\ ORCID: 0000-0002-3293-2377
}

\title{
MONEY LAUNDERING AS A MAJOR RISK TO THE STABILITY OF THE BANKING INDUSTRY
}

\author{
DOI: $10.15611 / \mathrm{pn} .2021 .4 .05$ \\ JEL Classification: G21
}

\section{(C) 2021 Marek Kot}

Praca opublikowana na licencji Creative Commons Uznanie autorstwa-Na tych samych warunkach 4.0 Międzynarodowe (CC BY-SA 4.0). Skrócona treść licencji na https://creative-commons.org/licenses/by-sa/4.0/deed.pl

Quote as: Kot, M. (2021). Money laundering as a major risk to the stability of the banking industry. Prace Naukowe Uniwersytetu Ekonomicznego we Wrocławiu, 65(4).

\begin{abstract}
This paper presents important and pending risks to the stability of the banking industry arising from the impact of money-laundering practices. The major focus is placed upon the proper organization of the terms typically employed in relation to the issue under study, supported by critical literature analyses and complete with an attempted evaluation of the potential effects of money-laundering processes. The paper provides an overview of the issue at hand without aspiring to form any exhaustive judgements. The marked dynamics of changes, both in the banking segment and its immediate environment, requires constant evaluation and observation, and this postulate applies also to processes associated with money-laundering. The wealth of the presented data may serve as the basis for further research of analytical approaches to the study of money-laundering practices.
\end{abstract}

Keywords: money laundering, stability, banking industry, economy, financial crime.

\section{Introduction}

Before proceeding with analytical evaluations of the money-laundering phenomenon, it may be useful to formulate a number of observations with regard to the informal (grey) economy as a domain bearing direct associations with the problem under study. The persistence of informal economic arrangements is apparent in all economies, and national differences are only manifested in regard to the extent of such practices. Numerous measures are employed in the study of this phenomenon, producing a wide spectrum of fairly discordant results (Hu, Pavlin, and Shi, 2013, pp. 250- 
-255). However, it may be safely stated that the larger the extent of the informal arrangements, the more pronounced disturbances can be observed at national level, due to the negative effects in such areas as (without limitations):

- fair market competition,

- public finance,

- the labour market,

- the private finance sector (Fundowicz, Łapiński, Wyżnikiewicz, and Wyżnikiewicz, 2020, pp. 9-11).

Poland's Supreme Audit Office (NIK) clearly identifies the grey economy as one of the most important barriers to national development. The implementation of legal regulations designed to combat the informal economic practices is largely focused on the markets of energy, tobacco products, ethyl alcohol, gambling, electronics, precious metals, and construction work (NIK, 2017, pp. 8-11). As evidenced in a later section of this paper, these areas are also quite prominent in the context of money-laundering methods and practices.

Based on the above definition of the grey economy, and bearing in mind its effects on financial stability at national (and sectoral) level, one may safely approach the task at hand, i.e. analytical evaluations of both the money-laundering phenomenon and of the available remedies. This type of crime presents one of the most critical risks to the financial sector, particularly the banking industry. Its negative effects upon legal business operations, goods and services pricing, savings, employment, and economic growth are fairly clear. In addition, the grey economy has a strong impact on asset liquidity, reputation and the stability of the financial sector (Siejczuk, 2012, p. 206).

According to UN estimates, proceeds of crime amounting to between 800-2000 billion USD each year are placed into legal circulation, representing anywhere between 2\% to $\%$ of the global Gross World Product (unodc.org, 2020). Despite such a large margin of estimates, even the lowest level of the reported amounts is alarming. No dependable estimates are available to describe the extent of money-laundering activities in Poland, but based on global data they may safely be assumed to present a sizeable percentage of the gross domestic product (in 2020, the nominal GDP for Poland was reported at around 2,323.9 billion PLN (Communication of the Chair of the Central Statistical Office, 2021)). In light of the above, the lack of legal state proceeds from informal operations has a sizeable impact on the national budget. Moreover, as banks are effectively removed from the economic turnover of grey economy proceeds, they face the risk of losing a sizeable part of their revenue. This may result in sectoral stagnation or even a reduction of employment, and has the immediate effect of reducing the volume of tax dues paid to the state budget (as the resulting loss in revenue is directly reflected in taxes paid by the sector). 


\section{The technical aspects}

Money laundering is a complicated process requiring considerable financial outlay. A broad spectrum of techniques, behaviour and procedures are employed for the purpose of procuring the final product in the form of financial assets which are legally approved in economic transactions. While such activities are often conducted in a legal manner, their only purpose is to obscure the illicit nature of the assets involved in the process. For this reason, the battle against money-laundering practices is burdened with considerable difficulties (Alsuwailem and Saudagar, 2020, pp. 833-834; Wąsowski and Wąsowski, 2001, p. 30).

Money-laundering processes involve a wide array of methods devised for illicit purposes (Irwin, Choo, and Liu, 2011, pp. 87-90). Table 3.1 presents an overview of the most common techniques utilized in this context, but it must be assumed that the informal economic operations conducted for criminal purposes include a sizeable array of hitherto undiscovered or unclassified activities. Another important challenge is the observed dynamics of changes in the studied phenomenon, as each and every progress in science, criminology and legislation is met with an active response from the criminal world intent on a rapid adjustment to the new social and legal obstacles to their illicit trade (Mazur, 2014, p. 54). It should also be noted that the informal activities are often conducted by professionals with years of experience and practice in finance. For these reasons, the state authorities should be intent on providing equally competent teams to control and contain the money-laundering problem as well as ensuring proper financial, personnel and (most of all) technological support for such units. The perpetrators of crime in their illicit activities place their main focus on concealing the true owner and the actual source of financial resources. They also underscore the need for retaining total control over the resources for the entire duration of the process and for minimizing the time assigned to each step of the process, with the intent of streamlining the exchange and reducing the risk of exposure and seizure (Hataley, 2020, pp. 654-658; Rysiński, 2015, pp. 59-60).

Professional literature identifies three main phases of the money-laundering process (Irwin et al., 2011, p. 87; Kunicka-Michalska, 2002, p. 66; Teichmann and Falker, 2020b, pp. 485-490; Whisker and Lokanan, 2019, pp. 158-172), namely placement, layering, and integration. It may be useful, however, to extend the list to include a preparation phase (Chodnicka, 2015, pp. 46-49). The postulated classification serves a theoretical purpose, as the phases in practical applications are often fluid, with blurred boundaries and overlapping segments (Siejczuk, 2012, pp. 201-202). This only adds to the difficulty in formal classifications of the studied processes. While the techniques presented below are associated with specific phases, it must also be borne in mind that some of them are employed in more than one phase of the process or adopted in a hybrid fashion. 
Table 1 presents an overview of selected money-laundering techniques ordered by phase (cf. P. Chodnicka). It is unfeasible to assume that a complete list of the methods can be produced, as many of them remain unrecognized. In an attempt to

Table 1. Money-laundering techniques

\begin{tabular}{|c|c|c|c|}
\hline Preparation & Placement & Layering & Integration \\
\hline $\begin{array}{l}\text { bulk cash smuggling, } \\
\text { trafficking, } \\
\text { purchase and transfer of } \\
\text { luxury goods, } \\
\text { cash deposits, } \\
\text { litigation agreements, } \\
\text { alternative banking } \\
\text { systems }\end{array}$ & $\begin{array}{l}\text { mutual compensation, bribery, } \\
\text { smurfing, } \\
\text { structuring, } \\
\text { purchase of cash substitutes, } \\
\text { such as traveller's cheques, } \\
\text { documentation forgery, } \\
\text { blending, } \\
\text { foreign currency trafficking, } \\
\text { currency exchange, } \\
\text { purchase of winning tickets } \\
\text { in cash, } \\
\text { purchase of tokens in cash, } \\
\text { followed by trade-in paid to } \\
\text { a bank account, } \\
\text { cashier's cheques and money } \\
\text { orders, } \\
\text { banking deposits, } \\
\text { purchase of financial } \\
\text { businesses, } \\
\text { instruments, } \\
\text { lending to a crime associate, } \\
\text { purchase of public tender } \\
\text { securities in cash, to be } \\
\text { returned to a bank account, } \\
\text { investing illicit capital via } \\
\text { a legal attorney, dummy } \\
\text { holdings } \\
\text { initial capital paid by a fake }\end{array}$ & $\begin{array}{l}\text { documentation forgery, } \\
\text { wire transfer via } \\
\text { multiple standing order } \\
\text { transactions, } \\
\text { switch box, } \\
\text { purchase of insurance } \\
\text { products and filing for } \\
\text { claims, } \\
\text { purchase of gemstones } \\
\text { and precious metals, } \\
\text { large numbers of } \\
\text { transactions made } \\
\text { without any economic } \\
\text { justification, } \\
\text { offshore bank accounts, } \\
\text { purchase of financial } \\
\text { instruments without } \\
\text { any consideration of } \\
\text { commission cost or } \\
\text { pricing trends, } \\
\text { transfers to bogus bank } \\
\text { accounts and bogus } \\
\text { recipients, } \\
\text { cross-linking of checking } \\
\text { accounts, } \\
\text { use of electronic forms of } \\
\text { payment, } \\
\text { chaining of independent } \\
\text { transactions }\end{array}$ & $\begin{array}{l}\text { use of artificial or } \\
\text { fictitious buy/sale } \\
\text { transactions, } \\
\text { raising the sum invoiced } \\
\text { for legally purchased } \\
\text { commodities moved } \\
\text { across national borders } \\
\text { to legitimize part of the } \\
\text { reported expenses, } \\
\text { acquisition of falling } \\
\text { businesses, } \\
\text { arranging mutual fake } \\
\text { loan schemes, } \\
\text { offering credits, loans } \\
\text { and other products to } \\
\text { legal entities on highly } \\
\text { competitive terms and } \\
\text { conditions, } \\
\text { loans taken and resolved } \\
\text { by immediate repayment, } \\
\text { blending, } \\
\text { durable goods trading, } \\
\text { use of long-term deposits } \\
\text { to secure loans taken } \\
\text { with another provider } \\
\text { (typically, an offshore } \\
\text { bank), } \\
\text { letters of credit, } \\
\text { the winning ticket, } \\
\text { between family members }\end{array}$ \\
\hline
\end{tabular}

Source: (Chodnicka, 2015, p. 49). 
mitigate the extent of money-laundering activities on the market, the Ministry of Finance prepares national evaluations of the associated risks (Internet 1, 2020). Evaluations are made separately by sector, including (without limitation): the banking industry, financial and payment institutions, brokerage, money-changing services, cooperative banking, the Central Securities Depository of Poland, insurance industry, and others. Both national and EU legislation, with formal support from financial institutions, law en-forcement agencies and cooperating institutional units, place strong emphasis on preventing and controlling the spread of illicit money-laundering activities. The requirement of presenting national evaluations of the associated risks is designed to support other instruments. Despite such concerted efforts, money-laundering retains its position of being a major threat to the global economy. Moreover, as already noted, this particular form of crime is often employed in tandem with other criminal activities, placing additional risks and increasing the potency of its effects upon specific segments of the national economy. Irrespective of the above, the financial sector is still the most vulnerable element, as the main environment hosting the majority of the studied illicit activities.

With all of the above techniques in mind, banks put a lot of effort into combating money laundering. The actions they are able to take often depend on the national implementation of anti-money laundering (AML) law. The implementation is assessed by the Financial Action Task Force (FATF), which also coordinates global efforts in combating money laundering (De Koker, 2014, pp. 282; Nanyun and Nasiri, 2021, pp. 232-235; Teichmann and Falker, 2020a, p. 3). One of the crucial steps banks take to combat the phenomenon is providing professional training for their personnel and raising awareness among the staff (Halawi, 2019, pp. 529-531). Teichmann and Falker pointed out that the effective combating of money laundering is being achieved through international cooperation with both private and public financial sectors. The main reason for this was the fact that cyber-crime has become much more international due to globalization. What is more, criminals use opaque financing systems and international company structures to aggravate local authorities tracing of transactions (Teichmann and Falker, 2021, pp. 3-4). To combat money laundering, banks do their best to implement the international and national AML regulations and standards. Complying with the required regulations will also allow them to avoid financial penalties imposed by the central supervisory institutions (Young, 2013, pp. 201-202). Another action taken by the banks is the development of artificial intelligence mechanisms. This is even more important nowadays, due to the significant increase of cyber criminals' activities. Increased number of cyber-crimes was caused by the transition of day-to-day processes to the online environment due to the lockdowns implemented worldwide as a response to COVID-19 (Herath and Herath, 2020, pp. 279-281). Given the large number of money transfers made every day, it is impossible for the available human resources to review them all, however this can be achieved by a sufficiently developed AI. (Wronka, 2021, pp. 7-8). These are just a few of the procedures developed by the banking sector over recent years; each and 
every one of them is extremely important in the effective combating the money-laundering process. If the banks happen to fail to prevent this phenomenon, the banking sector, and in the wider scope, the financial sector, will face the negative effects of money laundering.

\section{The economic effects of money laundering}

The stability of the financial system is the foundation of economic growth, both in the national and global dimension. The financial system is perceived as the most important element of the entire construct of the state and its economy (Gołębiewska, 2014, p. 40). This line of approach to the discussed problem can also be seen in the study by V. Beqiri and N. Beqiri. In their opinion, while the effects of money-laundering admittedly escape easy estimation, they are naturally detrimental to the stability of the financial system, identified as a key component of stable economic growth. Moreover, the phenomenon exerts a negative influence on the state budget by reducing state revenues and thus limiting the scope of public investments. Money laundering may also have a detrimental effect on the reputation of both state and individual institutions affected by this problem (Beqiri and Beqiri, 2018, pp. 88-89)

One of the most obvious observations is that illicit money-laundering practices largely serve to fuel economic crime. The economic effects of such practices can be detrimental on a regional, national, and even global scale. It may be worth noting that the effective economic impact of this particular form of crime escapes any reliable measure (Grzywacz, 2014, p. 104). The ubiquitous character of money-laundering practices and their extensive use by the criminal world is reflected in the number of critical economic setbacks and financial stability disturbances observed in many areas of the world. Gołębiewska suggests that money laundering may exert a destabilizing effect on national economies when the bulk of the proceeds from crime approaches the volume of the national GDP. Aside from the above, money-laundering practices may introduce disturbances in the fiscal system, incite corruption among officials of the relevant institutions, violate the principle of fair competition and support a hegemony of organized crime over selected segments of the national economy. Due to the volume of illicit transactions, money laundering may pose a critical threat to companies from the financial sector (including banks), but it may also affect their public image and reputation, to the extent of reinforcing the criminal dominance and indirectly increasing public acceptance for illicit alternatives. Thus, the ultimate effect may be that of inducing support for illegal 1 activities which place a direct risk to state security (Gołębiewska, 2014, p. 55). According to Elamin, the following major effects of money-laundering practices can be identified: decreased control of the state over the national economy, the resulting economic disturbances and instability, the risk of credibility loss, deterioration of the financial system, and disruption of capital market integrity (Elamin, 2018, p. 7). 
The destabilizing effect of criminal money-laundering practices is manifested in various ways, including:

- the disruption of fiscal and currency exchange mechanisms and systems;

- the stimulation of corruption among officials of public administration bodies responsible for the regulation of specific sectors of national economy;

- the violation of the fair competition principle and disturbance of market mechanisms influencing the major market parameters;

- the appropriation of control over specific sectors of the economy by organized crime groups (Grzywacz, 2014, pp. 105-106).

Money laundering has a direct negative influence upon production and investment; it also increases the risk of macroeconomic destabilization. Money legitimized via channels located outside the formal financial structure is placed in the so-called sterile investments ${ }^{1}$ or located in segments largely unproductive from the budgetary perspective of the national economy. In this way, the criminal world provides critical support and heavy investment for the development of façade structures designed solely to conceal the true source of profit, rather than contribute to the increase of productive and legitimate endeavours intent on the maximization of profit through the rational application of the market principles of supply and demand (Zali and Maulidi, 2018, pp. 47-51). In this way, a sizeable part of a nation's means of production volume is squandered in sterile investments instead of being spent on more productive ventures or standard consumption needs which, through increased demand, stimulate economic growth. This may result in major market disruptions (Mazur, 2014, pp. 28-29). In addition, when large volumes are laundered through the purchase of commodities (such as real estate), the increased demand leads to the rapid appreciation of prices - and this trend is typically reflected in other segments of the national economy. Moreover, the excessive pricing of commodities only serves to fuel the emerging incentives for investors to depart from the rational mechanisms of market play in favour of less productive, but more profitable ventures. Consequently, the production value of national economies troubled by money-laundering practices is well below that of the less affected countries. Hence the studied range of phenomena has the effect of reducing the effectiveness of national economies, translating into a marked reduction of the national income and employment (Jančíková and Veselovská, 2018, pp. 334-336).

As already noted, the introduction of illicit funds into formal circulation is also strongly correlated with corruption. In general, higher corruption levels correspond with a slower pace of economic growth. UN studies suggest that bribery and other forms of high-level power abuse are detrimental to national economies, as these practices are often closely related to (or supported by) organized crime groups.

\footnotetext{
${ }^{1}$ Sterile investments provide no dividends or interests. All gains from this type of investment come from price appreciation. Examples include real estate, art and collectibles, antiquities, jewellery, and other luxury items.
} 
Bribery hampers the development of legal businesses, distorts the effective allocation of resources, and undermines the authority and legitimacy of political decisions. As noted in the previous section, money-laundering practices and the associated increase of organized crime and corruption also affect the fiscal system, particularly the tax collection mechanisms (Reznik, Danylevska, Steblianko, Chekmarova, and Karelin, 2020, pp. 6-7). Since the main channels of tax avoidance practices are mostly observed in the SME segment, it must also be noted that these phenomena may constitute effective barriers to economic development, particularly for the emerging economies, as small and medium-sized companies are typically the most decisive elements of economic progress (Lewandowska, 2017, pp. 66-68).

The IMF formally identifies two principal mechanisms that contribute to the loss of macroeconomic stability in emerging economies caused by large volumes of criminal funds coming into circulation. The first group of factors is associated with the 'hot money' problem ${ }^{2}$, as a massive inflow of illicit capital is quite often observed in periods of political destabilization (Van Duyne and Soudijin, 2009, p. 187). Political disturbances, even in the short-term perspective, are typically reflected in economic instability, as the flows of illicit money are rarely persistent and highly unstable (Otusanya, Ajibolade, and Omolehinwa, 2011, p. 59). This results in an uncontrolled swings of money supply, currency exchange rates and commodity prices. Secondly, some of the phases of the money-laundering process include underground dealings which are difficult to estimate in formal statistical reports. Grzywacz introduced another group of factors responsible for financial stability disruptions, namely those responsible for the contagion effect. This term describes the permeation of the criminal world into the legal structures and institutions targeted or otherwise affected by money-laundering practices. As a result of the tight correlation between all elements of the financial sector, the problems faced by any institution tend to spread dynamically across the entire structure of associated actors and may ultimately affect the stability of the national economy as a whole (Grzywacz, 2014, pp. 112-113).

While the true extent of illicit activities is not sufficiently recognized, it is quite evident that the practices generate considerable flows of revenues and expenditure. By involving sizeable parts of human and capital resources for illicit activities, the criminal world effectively depletes the pool of resources available for legitimate endeavours, to the effect of disturbing the operation of formally recognized actors. However, in certain scenarios, the inflow of illicit capital may also produce a positive outcome. A good example of this mechanism is the tax haven strategy, i.e. a national strategy of economic growth founded on the inflow of foreign illicit capital, which sadly proves effective even in the face of high inflation rates or large budget deficits (Siejczuk, 2012, pp. 206-207).

\footnotetext{
${ }^{2}$ The term represents large money flows between financial markets conducted for short-term profit or as a safeguard against falling exchange rates. Hot money flows are often speculative in character, with a tendency to increase in periods of currency crises.
} 
To sum up, the consequences of money-laundering practices observed in the financial and other sectors of a national economy include the following:

- the placement of illicit funds in sterile investments, i.e. those that do not contribute to the gross national product;

- hampering legitimate investments through inflation of prices for commodities targeted by money-laundering practices;

- distorting the trade exchange structure;

- displacement of legitimate economic activity.

The EU member states are fairly divergent in their practical implementations of the European acquis. While many European countries maintain the highest standards required by the community, along with all the pertinent recommendations and guidelines of the organizations involved in the process of counteracting the money-laundering problem, the effective recovery of illicit profits remains in the range of $1.1 \%$ of the total volume. The bulk of illicit turnover is owned and controlled by the criminal underworld. Moreover, many governments and financial institutions voice their strong concerns that the present system for reporting questionable activities is ineffective, as even as many as 9 out of every 10 submissions prove to be of no immediate value to investigators (Internet 3, 2020).

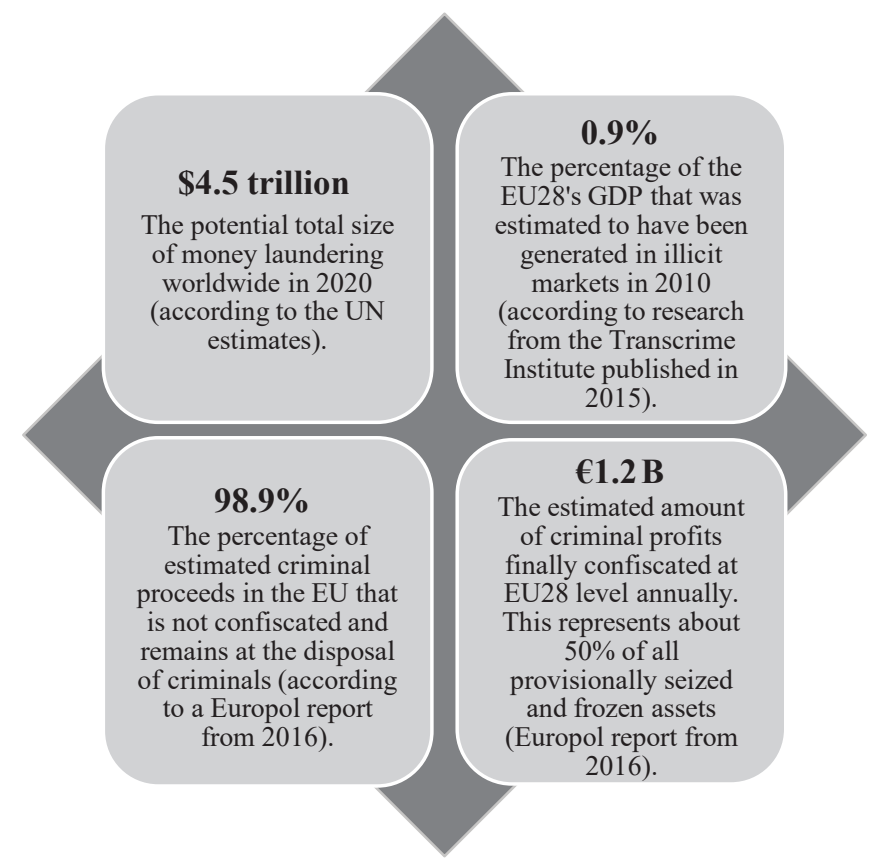

Fig. 1. The world's 'dirty money' by numbers

Source: based on data published at (Internet 3). 
Periods of financial instability present a special case for the studied problem, both nationally and globally, the best example being the present COVID-19 threat. The FATF report places a strong emphasis on the fact that the criminal underworld utilizes the crisis for illicit profits. These purposes are served by such opportunities as:

- the appropriation of public funds, virtual assets and financial services offered by the present increase of online transactions previously safeguarded by face-to-face standards of service;

- the appropriation of funds from support programs designed to provide aid to physical and legal persons afflicted by the crisis;

- the criminal permeation of high-outlay, high-liquidity businesses, for example those in emerging economies where prices and costs were momentarily more favourable, at least for criminal purposes.

The present pandemic itself has had a crippling effect on the governmental and sectoral potential to deal with and respond to the increasing wave of illicit financial practices, also in the context of implementing and reforming the associated legislation. Moreover, the crisis itself hampers the effective supervision of vulnerable sectors and organizations, mostly by introducing barriers to reporting, communication and international cooperation between AML actors (FATF, 2020, pp. 4-7).

With the view of improving the effectiveness of anti-money laundering interventions, the FATF recommends a number of strategies, including: encouraging the use of responsible communication and cooperation between governmental and private actors, supporting the use of electronic and digital payment methods, as well as undertaking pragmatic, risk-based AML/CTF supervision for the approval of simplified due diligence measures. After all, actions of the governmental and private sector organizations (particularly those of the financial sector) will decide on the future extent and spread of money-laundering practices (FATF, 2020, pp. 13-16; Murar, 2021, pp. 1-3).

\section{The adverse impacts on the banking system}

The legitimization of illicit money can be obtained through a variety of channels closely related to the services of formal institutions in the financial sector, including banks. The banking industry presents one of the most important elements of the studied phenomenon, and for this reason banks are particularly vulnerable to the negative effects of money laundering. The EU regulators are well aware of the problem, as evidenced by the increased regulatory responsibilities and legislative pressures placed upon the sector ${ }^{3}$.

\footnotetext{
${ }^{3}$ An explicit manifestation of this trend can be found in recent implementations of the amendments (March 30, 2021) to the Act on Anti-Money Laundering and Financing of Terrorism and certain other acts as well as the implementation of the VI AML Directive formally required from the Member States by December 3, 2020.
} 
Banking stakeholders are the main group affected by the negative effects of money-laundering practices (Demetis, 2018, p. 11). When a default on a bank's part produces a noticeable surge of attempts to launder money, or when information on a potential breach of AML measures becomes public knowledge, the main stakeholders of the affected institution (including creditors, holders of investment accounts and institutional clients) suffer the brunt of the loss. The negative effects are particularly painful to those stakeholders who place great emphasis on CSR issues. Bearing in mind the potential negative effects to their investments, the affected stakeholders may, in a manner of speaking, punish their banks for failure to adjust to the AML requirements (Schertler and Tillema, 2021, pp. 22-23).

Chodnicka provided the following catalogue of negative effects for the banking industry produced by the studied practices:

- the breach of the financial stability of a bank, and the associated risk of reputation loss;

- financial losses produced by the ill-advised actions of corrupted employees;

- the deterioration of trust placed in the entire banking system, both domestic and international (cf. Czarnota, 2014, pp. 154-156). This may result in a direct reduction of foreign investment or the inflow of capital in general. It may also increase the risk of a bank run.

- large inflows and subsequent transfers of dirty money may gravely affect the financial liquidity of the affected institutions (Chodnicka, 2015, pp. 71-73).

Economic growth requires a stable and healthy financial system of institutions, and this requirement is of particular importance for emerging economies (Khan, Jawaid, and Arif, 2018, pp. 429-430). The World Bank places the development of local capital markets and of the banking sector as one of the three indispensable conditions of economic growth (along with governmental reforms and the development of infrastructure (Timilsina, Hochman, and Song, 2020, pp. 13-15). Customer trust and positive reputation have a direct impact on the operation of financial systems, both in the developing regions and in the more affluent economies. The largest financial institutions of the developing economies were mostly developed on the basis of state-funded support rather than through private deposits. However, their present requirement for effective development is nonetheless relatable mainly to the level of trust placed in the institution by the private investors, in line with the recent trend of departure from state-owned capital in favour of private capital. If an emerging economy overlooks the money-laundering problem in their financial system, the natural result is the decline of trust placed in the system by private investors (Mohammed, 2020, pp. 103-104). In an international context, those of the emerging economies which fail to provide sufficient supervision and pertinent legislative measures in the regulation of their financial systems are prone to be contained by formal and informal economic sanctions imposed on the initiative of their strategic partners and major foreign investors. Such punitive measures may cripple the pace of national economic growth or even lead to severe financial disturbances (Hołda and Grzywacz, 2005, pp. 57-67). 
As pointed out by Williams, Slutzky and Villamizar-Villlegas, the corporate customers of banks affected by money-laundering practices may suffer more direct negative effects, such as the resulting changes in prices and terms of financing (Williams, Slutzky, and Villamizar-Villegas, 2019, pp. 24-26). Faced by the prospect of such an effective barrier to their development, the customers are more inclined to shift their assets elsewhere. This may not necessarily lead to a bank run, but the reduction of deposits and assets held will be rather visible.

Table 2. Effects of money-laundering practices

\begin{tabular}{|c|c|c|c|c|c|c|c|}
\hline \multirow[b]{2}{*}{ No. } & \multirow[b]{2}{*}{ Effect } & \multirow[b]{2}{*}{ 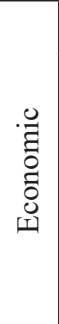 } & \multirow[b]{2}{*}{$\begin{array}{l}\text {. } \frac{\pi}{0} \\
0 \\
\text { n }\end{array}$} & \multirow[b]{2}{*}{ 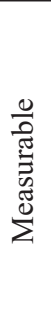 } & \multirow{2}{*}{ 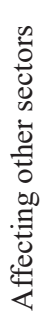 } & \multicolumn{2}{|c|}{ Span } \\
\hline & & & & & & 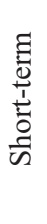 & 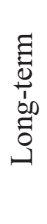 \\
\hline 1 & Distortion of investment and savings mechanisms & $\mathrm{X}$ & & $\mathrm{X}$ & & & $\mathrm{X}$ \\
\hline 2 & Distortion of fair competition & $\mathrm{X}$ & & & $\mathrm{X}$ & $\mathrm{X}$ & \\
\hline 3 & Negative effects upon national economic growth rate & $\mathrm{X}$ & & $\mathrm{X}$ & $\mathrm{X}$ & & $\mathrm{X}$ \\
\hline 4 & Changes in money demand, currency exchange, and interest rates & $\mathrm{X}$ & & $\mathrm{X}$ & $\mathrm{X}$ & $\mathrm{X}$ & \\
\hline 5 & Negative impacts on stakeholders & $\mathrm{X}$ & $\mathrm{X}$ & & & $\mathrm{X}$ & \\
\hline 6 & Destabilization of currency exchange rates and interest rates & $\mathrm{X}$ & & $\mathrm{X}$ & $\mathrm{X}$ & $\mathrm{X}$ & \\
\hline 7 & Credit accessibility & $\mathrm{X}$ & & $\mathrm{X}$ & & $\mathrm{X}$ & \\
\hline 8 & Increase of capital flows & $\mathrm{X}$ & & & $\mathrm{X}$ & $\mathrm{X}$ & \\
\hline 9 & Changes in foreign direct investment & $\mathrm{X}$ & & $\mathrm{X}$ & $\mathrm{X}$ & & $\mathrm{X}$ \\
\hline 10 & The risk of destabilization of the banking sector & $\mathrm{X}$ & $\mathrm{X}$ & & $\mathrm{X}$ & & $\mathrm{X}$ \\
\hline 11 & Revenues for the banking sector & $\mathrm{X}$ & & $\mathrm{X}$ & & & $\mathrm{X}$ \\
\hline 12 & Reputation of the banking sector & & $\mathrm{X}$ & & & & $\mathrm{X}$ \\
\hline 13 & Distortion of economic statistics & $\mathrm{X}$ & & & & $\mathrm{X}$ & \\
\hline 14 & Corruption and bribery & & $\mathrm{X}$ & & $\mathrm{X}$ & & $\mathrm{X}$ \\
\hline 15 & Reduction of capital inflow & $\mathrm{X}$ & & $\mathrm{X}$ & & & $\mathrm{X}$ \\
\hline 16 & Impediment of foreign investment initiatives & $\mathrm{X}$ & & $\mathrm{X}$ & $\mathrm{X}$ & & $\mathrm{X}$ \\
\hline 17 & Economic and legal sanctions & $\mathrm{X}$ & & $\mathrm{X}$ & & $\mathrm{X}$ & \\
\hline 18 & Limitation of banking secrecy & & $\mathrm{X}$ & & $\mathrm{X}$ & & $\mathrm{X}$ \\
\hline 19 & Outflow of assets and capital & $\mathrm{X}$ & & $\mathrm{X}$ & & & $\mathrm{X}$ \\
\hline 20 & Cost increases related to AML activities & $\mathrm{X}$ & & $\mathrm{X}$ & & & $\mathrm{X}$ \\
\hline 21 & Deterioration of trust & & $\mathrm{X}$ & & & & $\mathrm{X}$ \\
\hline
\end{tabular}

Source: own study. 
With the intensive spread of money-laundering practices comes the problem of the boundaries of a banking secret, the alleviation of which is one of the more frequent approaches in many AML procedures. As a result, the banking sector previously reputed for their discretion - is now obliged to disclose parts of their dealings (Raweh, Erbao, and Shihadeh, 2017, p. 142). The change of banking confidentiality provisions has already led to the identification and authentication of large volumes of dubious assets. Banking institutions are more inclined to conform to the demand, intent on preserving their reputation and mindful of the potential administrative penalties that may ensue.

Banking institutions are formally required to counteract the spread of moneylaundering practices, and this requirement is naturally burdened with additional cost (Kot, 2020, p. 11641; Bankowość przyszłości..., 2021, pp. 66-67). Thus, the increase of criminal activities will obviously be reflected in the sector's outlays, to cover for additional AML resources - this effect may surely be recognized as a direct loss for the banking industry. In a similar manner, the cost of investing in qualified personnel, training and IT infrastructure for the detection of dubious transactions should also be viewed as a direct cost incurred by banks in the studied context (Usman Kemal, 2014, pp. 416-427). Table 2 presents an outline of the most recognizable effects of the money-laundering practices identified in relation to the banking sector. These include all the aspects discussed above as well as other effects which, albeit less pronounced, may still result in a tangible loss.

\section{Conclusion}

The money-laundering phenomenon presents a critical threat to the financial stability of entire economies, particularly to the financial sector. The most acute effects are observed in the banking industry. Loss of customer trust may bring devastating consequences for individual providers and for the economy as a whole. Considering the added effects of disturbances of fiscal and currency exchange mechanisms, elevated levels of corruption, criminal domination over selected segments of the economy and obstructing legal business activities, it is apparent that the phenomenon of money laundering has a destabilizing effect on the economy, in the local, national and global dimension.

Taking into account the wealth of arguments provided in this study, it seems advisable to emphasize the need for the constant improvement of financial control mechanisms and systems, and for governments' involvement in providing an efficient structure for the identification and prosecution of individuals and groups involved in money-laundering practices. While the catalogue of economic effects of money-laundering is fairly well-documented, the effective provision of AML procedures requires further effort. It must be noted that the regulator, the prosecuting services and institutions are always one step behind the criminal fraternity, and perpetrators are unrestricted in their choice of methods as long as they yield an acceptable profit 
margin. In contrast with the opposing force of the authorities and law enforcement, the criminal underworld is often better equipped with competences and resources (both human and material) and reaps relatively higher profit from their operation. Thus the financial sector, the EU and local regulators and the law enforcement bodies should intensify their efforts to obstruct such practices and gain a 'one step ahead' position in this race.

Further research is also required to address the problems related to the collation and analysis of complete information on the processes observed under the popular term of money laundering. Such efforts would surely correlate with those spent on devising effective AML measures, as the latter may potentially transpire from a proper analytical evaluation of sufficient amounts of data. The present scope of information collected in association with the studied phenomenon is by far too inadequate to provide any reliable conclusions. It seems that such tasks are now best served by the new generation of Artificial Intelligence systems gaining a seemingly steady recognition from the banking industry.

\section{References}

Alsuwailem, A. A. S., and Saudagar, A. K. J. (2020), Anti-money laundering systems: A systematic literature review. Journal of Money Laundering Control, 23(4), 833-848.

Bankowość przyszłości zaczyna się dziś. (2021). Miesięcznik Finansowy BANK, 7(336), 66-67.

Beqiri, V., and Beqiri, N. (2018). Negative effects on the domestic economy caused by money laundering. KNOWLEDGE - International Journal, 27, 88-89.

Chodnicka, P. (2015). Regulacje i ryzyko sektora bankowego. Warszawa: Wydawnictwo Naukowe Wydziału Zarządzania Uniwersytetu Warszawskiego.

Czarnota, D. (2014). Bank jako instytucja zaufania publicznego w dobie kryzysu - mit czy rzeczywistość (pp. 154-156). Katowice: Uniwersytet Ekonomiczny w Katowicach.

De Koker, L. (2014). The FATF's customer identification framework: Fit for purpose? Journal of Money Laundering Control, 17(3), 282-284.

Demetis, D. S. (2018). Fighting money laundering with technology: The case study of Bank X in the UK. Decision Support Systems, 96-107.

Elamin, I. M. A. (2018). Is capital market integrity really essential for anti-money laundering (AML)? University of Sussex.

Fundowicz, J., Łapiński, K., Wyżnikiewicz, B., and Wyżnikiewicz, D. (2020). Szara strefa 2020 (pp. 9-11). Warszawa: Instytut Prognoz i Analiz Gospodarczych Fundacja Naukowa.

Gołębiewska, E. (2014). Pranie pieniędzy. Aspekty etyczne w systemie przeciwdziałania praniu pienię$d z y$. Warszawa: Difin.

Gray, R., Owen, D., and Sopher, M. J. (1998). Setting up a control system for your organization. Non-profit World, 16(3), 65-76.

Grzywacz, J. (2014). Pranie pieniędzy. Metody. Raje Podatkowe. Zwalczanie. Warszawa: Szkoła Główna w Warszawie.

Halawi, R. A. (2019). Dirty money in the banking sector. Journal of Money Laundering Control, 22(3), 527-542.

Hataley, T. (2020). Trade-based money laundering: Organized crime, learning and international trade. Journal of Money Laundering Control, 23(3), 651-661. 
Herath, T., and Herath, H. S. B. (2020). Coping with the new normal imposed by the COVID-19 pandemic: Lessons for technology management and governance. Information Systems Management, 37(4), 277-283.

Hołda, M. i Grzywacz, J. (2005). Ekonomiczne skutki prania brudnych pieniędzy dla gospodarki globalnej i lokalnej. In J. Grzywacz (Ed.), Pranie brudnych pieniędzy. Warszawa: Oficyna Wydawnicza SGH.

Hu, M., Pavlin, J. M., and Shi, M. Z. (2013), When gray markets have silver linings: All-unit discounts, gray markets, and channel management. M\&SOM-Manufacturing \& Service Operations Management, 15(2), 250-262.

Irwin, A. S. M., Choo, K. K. R., and Liu, L. (2011). An analysis of money laundering and terrorism financing typologies. Journal of Money Laundering Control, 15(1), 85-111.

Jančíková, E., and Veselovská, S. (2018). The new technologies and the fight against money laundering and the terrorism financing (Second International Scientific Conference on Economics and Management - EMAN).

Khan, W. A., Jawaid, S. T., and Arif, I. (2018). Where does a nation's wealth go? Evidence from a ThirdWorld country. Journal of Money Laundering Control, 21(3), 426-476.

Kot, M. (2020). Impact of the 5th anti-money laundering directive on the EU's financial market. In K. S. Soliman, K. S. Soliman (Eds.), Education excellence and innovation management: A 2025 vision to sustain economic development during global challenges (pp. 11641-11646). International Business Information Management Association (IBIMA).

Kunicka-Michalska, B. (2002). Pranie pieniędzy i związana z tym korupcja w systemie bankowym w Polsce. Zagadnienia podstawowe. In J. C. Ferre Olive (Ed.), Blanqueo de dinero y corrupcion en el sistema bancarioSalamanca: Ediciones Universidad de Salamanca.

Lewandowska, K. (2017). Zjawisko prania brudnych pieniędzy. Journal of Finance and Financial Law, $4(16)$.

Mazur, M. (2014). Penalizacja prania pieniędzy. Warszawa: Biuro Rzecznika Praw Obywatelskich.

Mohammed, S. A. S. A. (2020). Money laundering in selected emerging economies: Is there a role for banks? Journal of Money Laundering Control, 24(1), 102-110.

Murrar, F. (2021), Adopting a risk-based approach for non-profit organisations. Journal of Money Laundering Control. (Ahead of print).

Nanyun, N. M., and Nasiri, A. (2021). The role of FATF on financial systems of countries: Successes and challenges. Journal of Money Laundering Control, 24(2), 232-243.

Otusanya, O. J., Ajibolade, S.O., and Omolehinwa, E. O., (2011). The role of financial intermediaries in elite money laundering practices evidence from Nigeria. Journal of Money Laundering Control, 15(1), 58-84.

Raweh, B., Erbao, C., and Shihadeh, F. (2017). A review the literature and theories on anti-money laundering. Asian Development Policy Review.

Reznik, O., Danylevska, Y., Steblianko, A., Chekmarova, I., and Karelin, V. (2020). Current status and prospects of anti-money laundering in a digital economy (REICE - Revista Electrónica de Investigación en Ciencias Económicas).

Rysiński, M. (2015). Ocena metod przeciwdziałania praniu pieniędzy. Warszawa: Szkoła Główna Handlowa w Warszawie.

Schertler, A., and Tillema, S., (2021). Market discipline effects of anti-money laundering infractions: Evidence from international banks (World Finance Conference).

Siejczuk, P. (2012). Zjawisko prania brudnych pieniędzy w regulacjach prawnomiędzynarodowych, europejskich i krajowych. Bezpieczeństwo Narodowe, (III-IV).

Teichmann, F. M., and Falker, M.-C. (2020b). Money laundering through consulting companies, Journal of Financial Regulation and Compliance, 28(3), 485-500.

Teichmann, F. M. J., Falker, M. -C., (2020a). Money laundering - the gold method. Journal of Money Laundering Control. (Ahead of print). 
Teichmann, F. M., and Falker, M. -C., (2021). Money laundering via underground currency exchange networks. Journal of Financial Regulation and Compliance, 29(1), 1-14.

Timilsina, G., Hochman, G., and Song, Z. (2020). Infrastructure, economic growth, and poverty. World Bank Group.

Usman Kemal, M. (2014). Anti-money laundering regulations and its effectiveness. Journal of Money Laundering Control, 17(4), 416-427.

Van Duyne, P. C., and Soudijin, M. R. J. (2009). Hot money, hot stones and hot air: crime-money threat, real estate and real concern. Journal of Money Laundering Control, 12(2), 173-188.

Wąsowski, K., and Wąsowski, W. (2001). Pranie brudnych pieniędzy. Poradnik dla bankowców (wraz z tekstem ustawy z 16 listopada 2000 r.). Warszawa: Biblioteka Menedżera i Bankowca.

Whisker, J., and Lokanan, M.E. (2019). Anti-money laundering and counter-terrorist financing threats posed by mobile money. Journal of Money Laundering Control, 22(1), 158-172.

Williams, T., Slutzky, P., and Villamizar-Villegas, M. (2019). Drug money and bank lending: The unintended consequences of anti-money laundering policies (Working Papers 2019-5, The George Washington University, Institute for International Economic Policy, revised May 2020).

Wronka, C. (2021). Cyber-laundering: The change of money laundering in the digital age. Journal of Money Laundering Control. (Ahead of print).

Young, M. A. (2013). The exploitation of offshore financial centres. Banking confidentiality and money laundering. Journal of Money Laundering Control, 16(3), 198-208.

Zali, M., and Maulidi, A. (2018). Fighting against money laundering. Brics Law Journal, 5(3), 40-63.

\section{Online sources}

[1] https://www.gov.pl/web/finanse/krajowa-ocena-ryzyka-prania-pieniedzy-oraz-finansowaniaterroryzmu

[2] https://www.iaml.com.pl/wiedza/aml-compliance-spowolnienie-gospodarcze/

[3] https://www.riskscreen.com/kyc360/news/the-worlds-dirty-money-by-the-numbers/

[4] https://www.unodc.org/unodc/en/money-laundering/globalization.html

\section{Other sources}

Communication of the Chair of the Central Statistical Office dated May 13, 2021, on the preliminary estimations of the value of Poland's Gross National Product for the year 2020.

FATF. (2020). COVID-19 related money laundering and terrorist financing. Risks and policy responses.

Najwyższa Izba Kontroli [NIK]. (2017). Działania organów kontroli skarbowej i organów stużby celnej $w$ celu ograniczenia szarej strefy $w$ gospodarce. Informacja o wynikach kontroli. Reg. No. 15/2017/P/16/010/KBF, pp. 8-11. 


\section{PRANIE PIENIĘDZY JAKO ISTOTNE ZAGROŻENIE STABILNOŚCI SEKTORA BANKOWEGO}

Streszczenie: Artykuł przedstawia ważną i aktualną problematykę wpływu procesów prania brudnych pieniędzy na stabilność systemu bankowego. Celem artykułu było uporządkowanie terminologii omawianego zagadnienia, krytyczna analiza literatury oraz próba identyfikacji potencjalnych skutków prania brudnych pieniędzy. Artykuł ma charakter przeglądowy i nie wyczerpuje omawianego problemu. Dynamika zmian zarówno w systemie bankowym, jak i w jego otoczeniu wymaga stałej obserwacji procesów w nim zachodzących, w tym także procesów związanych z praniem brudnych pieniędzy. Zebrane przez autora dane stanowią podstawę do prowadzenia dalszych badań w zakresie opracowywania sposobów analizowania tych procesów.

Słowa kluczowe: pranie pieniędzy, stabilność, sektor bankowy, gospodarka, przestępstwa finansowe. 